\title{
Illicit Drug Syndication Threat towards Juvenile in Malaysia
}

\author{
Zarina Othman Dan Mohamad Daud Druis \\ The National University of Malaysia, Bangi, Selangor, Malaysia \\ mdaud007@yahoo.com
}

\begin{abstract}
The issue of international drug abuse and illicit drug trafficking is a problem that is often associated with transnational organised crimes. Malaysia is of no exception where the threat from drug syndicates has become more prevalent especially since the existence of the internet facilities all over the world. Thus, this paper examines the reason why the juvenile are exposed to illicit drugs and are vulnerable to become victims to these substances to an extent that they are caught as Juvana offenders. This paper applying neolibralisme theoretical approach, as a guiding and analyzing the issue of juvenile involvement in illicit drug trafficking in Malaysia. Primary data was collected through document analysis, interviews, and for the case study, an interview was carried out on selected Juvana offenders. The findings of the research have shown the roles of the syndicates, to recruit the juvenile as trafficker as well as to bind them from staying away from the syndicate after they are released from the detention. It is hoped that by creating a more effective and systematic policy, the threat on juvenile from the illicit drug issue can be addressed accordingly and in turn, will enable them to contribute to the development and security of the country in the future.
\end{abstract}

Keywords: Illicit drug, security, neolibralisme, syndicate, juvenile

\section{Introduction}

In the region of the South East Asia, the threat of illicit drug syndicate has a very long history and has been a problem that is difficult to solve. This is because one of the hubs of the world's drug production is located in this region, namely the Golden Triangle. Moreover, the illicit drug-related crimes have also gained serious attention of researchers or scholars at the international level (Nichol, 2011). This is due to the fact that the threat from drug involves group crime that get across the boundaries of a country. This activity has become a very important issue, it can affect the sensitivity of the relationship between the neighbouring countries of South East Asia. It will also affect bilateral relations between two nations as they would be blaming one another as the root cause of the problem (Nalin, 2007). The affected relation would lead to the reluctance of these affected nations to cooperate with each other in addressing as well as curbing these cross-boundary crimes. Therefore, as one of the developing countries in the South East Asian region, Malaysia has the potential to engage in various activities involving trading of legal and also illegal trading. However, illegal trading and activities that are breaking the laws are also happening due to its strategic position in the South Asian (William et al., 2000). According to Adeeba (2013), who is a scholarly expert in the drug issues in Malaysia, the drug issue is becoming an increasingly serious issue in Malaysia. She contends this based on reports in mass media and the seriousness can be seen from the statistics of arrests made by the authority, which shows the increase in drug trafficking and drug addiction every year. This trend has shown a gradual shift of interest of the drug users from abusing traditional-type drugs such as heroine and marijuana, to synthetic drugs like Syabu, Eramine 5, Ketamine and ecstasy.

Today, drug abusers are also prone to use various types of drugs (traditional and synthetic) at the same time (Daniel, 2013). Statistics shows that in 2010 alone, the overall arrests for narcotics violations in Malaysia that involve synthetic drugs like Syabu, Ketamine, Ecstasy, Erimine-5 and Yaba increase to 44 percent compared to that for 2009. This total increase is quite worrying if compared to the increase in 2009, which is by 10 percent compared to 2008 which was 34 percent. Although the current generation clearly shows the inclination to abuse synthetic drugs, traditional drug issues such as heroine, still serve as the main threat to our nation (Abdullah, 2012). Drug abuse in Malaysia has become a great cause for concern due to the increasing figure and the increased severity of the issue. In 2010 , arrests involving heroine drugs were recorded to be $42 \%$ out of the whole drug-related arrests in Malaysia. The Royal Malaysian Police (RMP) Yearly Report (2011) claims that law enforcement has not been carried out as 
seriously and effectively as it should be, and the fact that the country has the potential to become a drug hub is consistent with the globalisation of drug trafficking, and the existence of illegal laboratory processing drugs at a grand scale (Metro, 2011). Other than that, there are an increasing number of foreign illicit drug syndicates detected, where they bring in drug experts to Malaysia to process drugs in this country, collaborating with local illicit drug syndicates. The involvement of this syndicate, has been brought out in the open several times, by the Malaysian authorities, where several laboratories processing syabu illegally are found in Semenyih (Selangor), Senai (Johor) and Bukit Jambul (Pulau Pinang) (RMP Yearly Report, 2005: 2009:2010:2011).

Apart from that, a lot of syndicates have been brought down as in cases that have attracted the world like the biggest syabu-related arrests in Pahang worth RM 254 million (Utusan Malaysia, 9 May 2009), three drug-trafficking groups arrested (Utusan Malaysia, 31 March 2010), Police nabs RM 7.5 million of Eramine 5 (Utusan Malaysia, 5 May 2011), drug value burned in factory worth RM 18 million (METRO, 14 June 2012). This demonstrates that illicit drug trafficking in Malaysia has become more and more serious and the non-state actor has been going rampant in these activities. Drug addiction is also at a critical level where it is estimated that one out of four Malaysians is a drug addict (UNODP, 2007). In terms of drug abuse and addiction in Malaysia, the trend of addiction seems to be more striking in economically developed states and territories. Kuala Lumpur, Pulau Pinang, Selangor, Johor and Perak are among the states that have contributed a great deal towards the total number of drug addicts in Malaysia.

\section{Chart 1: The Total Accumulation of Drug Addicts (1988 -2012)}

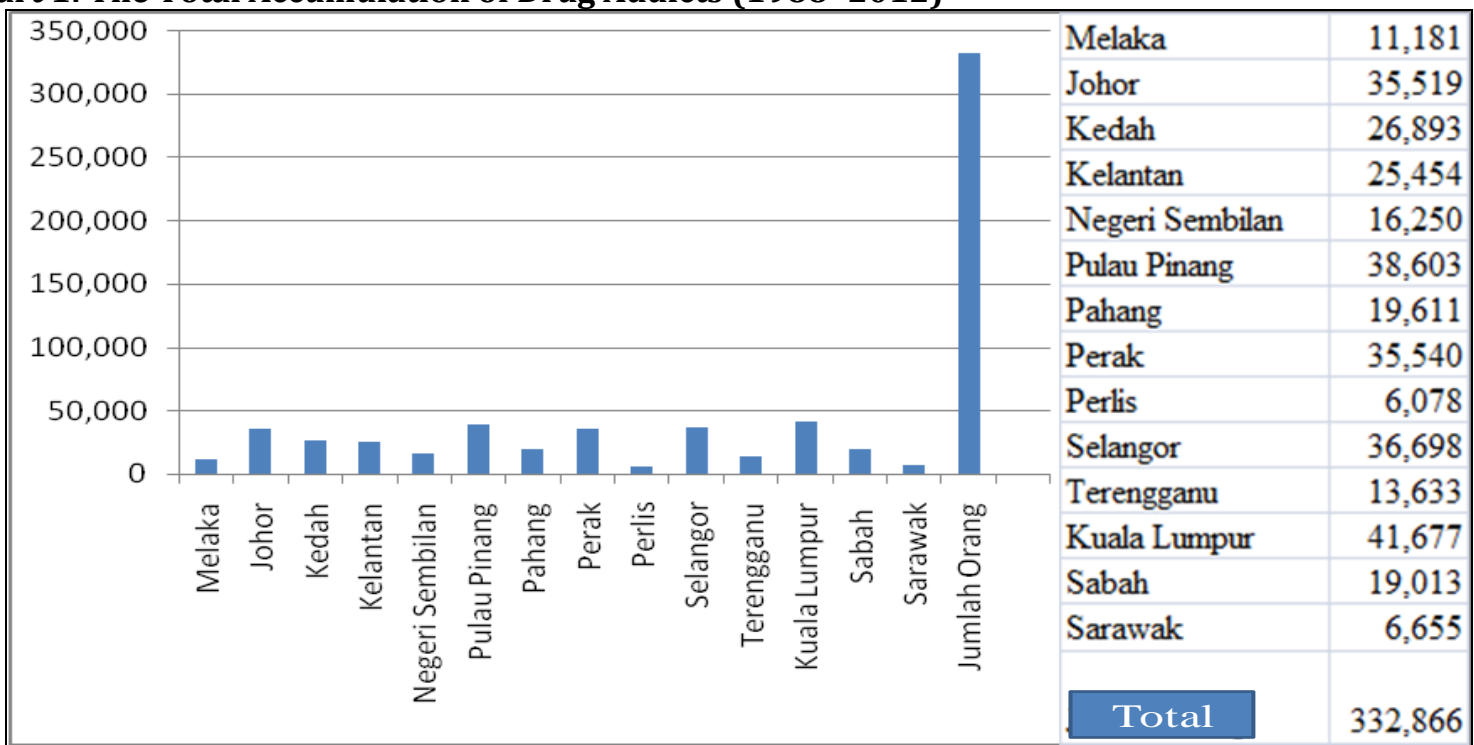

Source: Edited from National Anti-Drug Agency Report From 1988 To 2012

According to the National Anti-Drug Agency (NADA), from 1988 up to 2002 there were 235,495 people, and including about 50,000 were active drug addicts. Non-governmental organisations (N/G/O), such as Malaysian Drug Prevention Association (2011) estimated that about 350,000 people have been involved in drug abuse in this country. This number is said to have increased to about 1,300 drug addicts every month. The total number of drug addicts since the year 1988 to 2012 is as shown in Chart 1 . This is getting more and more worrying as the operating syndicate has started to involve not only adults, but also the younger ones, or the juveniles. This illicit drug syndicate serves as an organisation, that, in reality is in existence but is hard to pin down, as they operate in a system that is hard to detect (Hussian, 2013). In relation to the role of the non-state actor (syndicate) who plays their role in the illicit drug trafficking activities, they also try to approach and threat juveniles. Juveniles (teenagers) as defined in various dictionaries, or teenagers means someone who is entering adulthood, has reached puberty or is young. In regard of age, teenagers are perceived to be between 10 and 19 years old. Psychology-wise, the teenage phase is a phase of transition that continuous from childhood to adulthood and which is full of life conflicts (Mohamed, 2008). In this period, teenagers begin to be exposed to the wider world out of their own homes, one which is now acting as their second home. They also begin to learn a lot of things that may not necessarily come from their parents but mostly from the social environment in which they are raised. It is during these periods that teenagers start to change their way of behaving, their attitude and 
values, even the entire way of life from childhood to a world that is more mature and grown up (Khulen, 1982; Noraini, 2000).

When they commit a certain crime and are sentenced with light or heavy punishments or involved in group crimes, then this group will be categorised as Juvenile delinquents (2001 Child Act, 2006) Juvenile crime refers to acts of crime or anti-social acts committed by juveniles (teenagers), whereby crimes of this type are something that is more and more worrying everyone all over the world. It is a crucial social issue as this group has the capability to commit serious crimes, and yet they cannot fully be held accountable. Teenagers constitute a generation that inherits our country in years to come. A lot of hopes have been placed on them; they are expected to grow to become useful and resourceful individuals and are able to contribute to the country's wellbeing (Hussian, 2013). This article will explain about the threat of the syndicate imposed on the juveniles in Malaysia. Juvelines are a group who is very much susceptible to the influence of drugs, aged between 18 years and below (Kamus Dewan, 2006). In Malaysia juveniles aged as early as 10 years old are recruited as the syndicate as small-time traffickers in school (Utusan Malaysia, 29 March 2014). Therefore, teenagers must be seen as having to undergo a long period of transition, whereby their journey may not be free from pressure and a lot of barriers in the form of life conflicts bebas (Hasnah Ghani, 1995; Karl, 1975). During this phase, an individual will experience some very fast-paced changes, either physically, emotionally or even socially. This article revolves on a case study involving a juvenile, who has committed a Juvenile crime, discussing his background academically, economically, also his lifestyle as a victim of drugs. Other than that, the outcome of the interview with the respondent will also be discussed, and the socio-economic sustainability of juvenile victims from drug threats in Malaysia elaborated.

\section{Theoretical and Conceptual}

In discussing drug cases involving group crime, this article will use the neo-liberalism theory as guideline in analysing the role and impact to the juveniles. The neo-liberalism theory can explain the role played by the non-state actor including (criminal/syndicate) and also security issues transcending the boundaries in the context of globalisation as the main actor. In this vein, in a lot of debates concerning crossboundary crime cases and their relations with international security, this issue stays among issues of focus and which is emphasised by the regime (Rapley, 2004). Debates between neo-liberalist thinkers with regards to new security issues, explain that the non-state actor activities are thought to provoke fear. The role that they play is dangerous, affecting human security in their countries, where they operate through an international crime network (Owen, 2008). The neo-liberalism theory centralises on the wellbeing of the economy to countries practising free market. One criticism of this theory lies in the fact that people become selfish, and they carry out their activities through the free market without accounting for a country's sovereignty. In elaborating on the role played by the non-state actor in this theory, they cannot care less about the susceptibility of the economy of the country they go into. Thus, the non-state actor who is also comprising of multi-national business, that has a connection or network with international syndicates, then collaborate in doing illegal activities like drug to reap great profits (Nick Croft, 6 may 2013). Due to this widespread, the country's security will easily be affected, in terms of its sovereignty and human wellbeing.

\section{Methodology}

This article employs methods, namely qualitative, and also data involving the statistics from the Malaysian authorities, as they had collected both primary and secondary data. To study the impact of drugs on human security, this study has designed, collected and analysed the data, so that it will produce a pattern and some facts that can facilitate the analysis (Wagenen, 1991). The primary data were obtained through the method of interviewing main informants from several authoritative agencies handled by the government and private bodies which are non-governmental organization. Other than that, this study involves the interview of experts in certain fields such as pólice officers, medical officers, and National Anti-Drug Agency officers also Narcotics Rehabilitation Agency officers. Among the agencies that are directly involved in this study are the National Anti-Drug Agency (NADA), Royal Malaysian Police Force (RMP), Malaysian Health Ministry, Non-governmental Organization (NGO'S), and interviews were also conducted with juvenile delinquents in prison. Face-to-face interviews with informants in this study will be able to help in the development of more credible and effective data. Meanwhile, department 
documents and yearly reports, minutes of meeting, newspapers, personal documents such as diaries, letters or journals in the mini library of the department, also serve as materials of reference in this study.

Meanwhile, the secondary data from printed materials and documents, including books and government reports, documents by the NGO and United Nations that established previous studies can also serve as reference in the data collection (Mauch \& Birch, 1993). This article is written and supported by reviews of past academic studies covering books, journals, thesis/dissertations and monographs related to this article's title of research. This study also uses several related websites, among which include World Health Organisation, National Institute of Drug Abuse dan the Drug Policy Alliance websites. These agencies are important as they have a treasury of various data and information related to the study. This is because there are data that can only be obtained through websites and after the data are gathered, researcher has been able to see the trend and pattern that can facilitate the analysis of findings and conclusion of the study.

\section{Illicit drug syndicate and Threats on Juveniles in Malaysia}

United Nation Office on Drugs and Crime (2007), has issued a statement that the involvement of juvenile in prohibited substance abuse at the global level, is on the rise. The popularity of recreational drugs, free lifestyle, various external influences and also easy access to psychoactive materials have caused the teenagers to become more susceptible and embroiled into substance abuse in western countries. Following Mohamed (2008), this trend is also rampant and has been monitored in Malaysia where the number of teenagers abusing prohibited substance is on the increase every year. Also, the Head of Director of National Anti-Drug Agency maintains that such a widespread happens not only in large towns, but also in villages including the most worrying in Federal Land Development Authority (FELDA) settlements. The FELDA areas have attracted the syndicate groups as these places are very profitable for them, since FELDA residents tend to have the financial ability to get the substances (Berita Harian, 26 June 2013). The National Drug Information System Unit or Unit Sistem Maklumat Dadah Kebangsaan (NADI), displays statistical data showing some drug addiction issues detected all across the country for January to September 2008, and by average, 520 new addicts were detected within a month and 590 more were recidivists. This implies that, in average there are 17 new addicts and 20 recidivists detected every day (National Anti-Drug Agency, 2008). The newspaper New Straits Times dated 8 September 2009 has reported that as many as 306 school students aged 13-17 years old were found to be drug-positive through their urine tests done in the period of seven months in 2009 as compared to 115 cases in 2008, simultaneously showing a triple increase. This mirrors the fact that drug abuse has become prominent as a problem that burdens our younger generation (Ramly, 2012).

Responding to that statistics, after 30 years since 1983, Malaysia has carried out some actions such as arresting, charging and imprisoning drug offenders, as ways to curb the syndicate activities. However, the syndicate is still on the loose, where they are free to recruit drug addicts, traffickers and they even seem to show great success in operating, and even contribute to its severe widespread (Ibrahim, 2012). This means that, our approach which is more concerned towards national security, is quite ineffective in fighting against the syndicate. The national security approach means the implementation in regard of enforcement such as taking actions, arresting and charging drug offenders in the Court. Despite spending more than three decades carrying out drug enforcement according to the existing drug laws, Malaysian communities are still open to the ongoing threats of drug addiction and trafficking. A scholar who is an expert in the field of drug counselling is Hussien (2013). He claims there are many issues that arise such as the fact that the higher number of staff and the general public dealing with drug issues, are still unclear about any actions that have been undertaken by the authorities. Policy implementation to curb the syndicate activities necessitates some new, more robust approaches to ensure that a policy would work fashionably well. Studies show that the network of crimes spreads in countries which fail to uphold their law enforcements and this non-state actor can go on and proceed to bring chaos into the countries due to the frail institutions, bribery-succumbing officers, and generally weak society as has been stated by Low (1986). Despite the fact that sovereigned countries must have their respective laws and regulations, these non-state actors (criminals/syndicate) would still be able to influence the juveniles through various other media.

In relation to this, the role of the authorities in combatting the syndicate, has been weakening, or in other words, not really working successfully despite the fact that the highest rulers of the countries have 
declared war on drugs for the past 30 years. Malaysia, is not only still seen to fail to win this war but also has to brave an even more serious battle when there emerges new types of drugs. Criticisms towards the implementation of actions in combatting the illicit drug syndicate and to cure victims of drugs are very difficult to beat simply because our so-called opponents are non-state actors. A professor from the Dean of Medical Faculty in the Universiti Malaya, Adeeba (2013) claims that for sure, the seriousness of the impacts is only felt by Malaysia. She is quoted to have said this:

"...are we winning in this battle...the answer is No. This is because we cannot fight this war through what..? the slogan war on drugs, has been around for quite a while now.. and indeed we can never win. So now we are only focusing on wishing for them to go into the jail. But in reality, we do not have an all-round view of this drug issue..".

Although national security approaches like 'arrest and charge' in the court are employed by the government to combat the syndicate, new methods and strategies need to be thought out and they must cater for the current demand and situations at the global level. current situations mean, that in the international systems, a lot of countries have changed their approach in combatting drugs and this issue will become more serious as the syndicate tends to involve the juveniles.

The Impact of Juveniles' Survival of Life: The debate on the concept of survival of a country or a society depends on its socio-economic state. It is related to drugs and socio-economic security under the umbrella of human security. Meanwhile, the socio-economic security due to drugs is something that is very important to be studied at the expense of individual life survival. This can be seen from the perspective that is more focused on the victims involved with both illicit drug trafficking and addiction. Thus, this article only discusses the aspect of socio-economic security with regards to the safety of juveniles' education. Peer influence is also one of the high-risk factors that lead to substance abuse among teenagers. Teenagers who happen to have close friends already involved in substance abuse have higher tendency to also take part in this symptom (Azlan, 2013). The most apparent impact from drug syndication seems to relate with the factor of the juveniles' survival education. In this section, one important thing is the element of survival education for drug victims. Education-wise, one consequence for human security is the abandonment of education that causes the victims to have a very bleak future. Education is of utmost importance for human development and also for the development of the community and the country (Ibrahim, 2012). This element influences, and gives an impact to the sustainability in terms of the safety of the occupation, that is one that is accepted by the community, or in other words, which does not violate the norms of the community such as being halal in Islam. Reviewing on this second element, in terms of illegal occupation which is the threat that comes from drug activities, this will cause the surrounding community to become aware of it, and also there will emerge the perception of its danger. The juveniles' involvement with the syndicate such as addiction activities, drug trafficking, theft, robbery and other criminals will all contribute to their life survival (Sujak, 2013).

Survival of Education: Also, in the stream of literature concerning the survival of education, a lot of drug victims will be stucked in the middle, and this means that they will be experiencing this during their teenage years. This is explained by an informant named Rohaida Razali (not her real name) (2 February 2013) the most challenging age for a juvenile is between 13 and 20 years old, based on her experience being a drug victim and his disinterest in school at her tender age of 15 . During school hours, they would loiter and take drugs in groups in someplace remote from the school. This was the precursor to other effects on the juveniles such as their failure to excel academically in school unsafe school surrounding, chaos and the lack of faith given by the teachers - they are all influencing substance abuse among teenagers (Substance Abuse and Mental Health Services Administration, Centres for Substance Abuse Prevention, 1999). The increase in substance abuse among teenagers is closely linked with academic achievement that is not really satisfactory. The academic failure serves as one of the risk factors in the increase of prohibited substance abuse among this group. The increase of teenagers' involvement in this moral decadence is also contributed by the mushrooming and growth of adult entertainment centers. There are even a lot of students and teenagers visiting these centers to try out the vast array of drugs just for the pleasure of it (Razali, 2013). This is very worrying due to the fact that negative activities will definitely affect their education survival and all in all, their future.

Susceptibility, in terms of elimination from the stream of education can threaten their future when they have become involved in drugs. This poses a threat to the juveniles whereby they will be out of the cocoon of being a student to a drug victim. An Expert Professor in Drug Counselling and a specialist in 
General Health, Ibrahim (2012) states that juveniles who neglect going to school, that can be labelled 'out of school', are the most under threat. This is because they will get carried away and get drifted in the surge of development that distracts them, so much so that they will be entrapped into the grip of drugs. Once they are in it, their future will be bleak, due to the negative stigma embedded in the community towards drug victims. This is very worrying, as the future generation is one that does not prioritise education. Education is vital to ensure an individual's sustainability to ensure that his or her future is bright. However, as it is today, a lot of students do not see education is crucial to them, but instead they would rather have fun and engage in ill-meaning activities (Ibrahim, 2012). The statistics from the Malaysian Royal Police Narcotics Crime Investigation Department (2012) shows support to this fact, where the arrests made by the authority have demonstrated that the number of victims, from among youth in schools and Higher Learning Institutes, are on the increase, every year.

Based on the statistical report of arrests made of juvenile students and youth studying in the HigherLearning Institutes, these groups are also easily exposed to trafficking and addiction. In 2008 there were 265 people arrested, and it went up to 438 people arrested, although there was a slight reduction in terms of figures in 2010 and 2011. However, the figure increased dramatically up to 30 percent (442 people) for the year 2012 compared to (340 people) in 2011. For school students, there is even a more remarkable increase which is around 196 students in 2008, and in the following year it escalated to 340 students. Although the arrest in 2011 had decreased by almost $20 \%$ which is 335 people compared to 2010, it escalated drastically in 2012 represented by 64 percent (520 people). Therefore, education is crucial to an individual as it will also indirectly determine if the society is 'good' or otherwise. Other than that, the level of education of an individual will determine the level of thinking that he or she has, as well as influencing the type of work they would do in the future.

Case Study: In relation to the issue of security the survival security of juveniles due to drugs is quite remarkable, after an interview was carried out to juveniles involved directly with this issue. Subsequently, in understanding the problems faced by drug victims, interviews were carried out with those involved and those still undergoing sentence in a Malaysian prison. Next, several empirical examples are highlighted to show the socio-economic state of the juvenile addicts and traffickers with respect to education and occupation. We present here the profile of individual juvenile undergoing sentence in prison on the basis of drug offences, where it shows juvenile's educational background, occupation, his journey of life being involved in drugs as he was threatened by the syndicate.

Case One: Mohamad Nazrul Zulmie (not informant's real name), is a teenager aged 16 years old from Semenyih, Selangor, Malaysia. He is in Form Three and is still schooling in one secondary school in Semenyih. He was held in prison on the charge of possessing syabu that would bring him to a 5-year long imprisonment. He was first involved in addiction since he was 15 , where the drug was given to him by his friends free of charge. His history with syabu started when he and his friends had started to take drugs in school together. Subject's parents earn their income by having a small clothing business in the Semenyih town. Due to financial constraint, the subject decided to sell drugs or syabu. This was done as a small-time business. He went to see, and expressed his intention to work with the illicit drug syndicate in the Semenyih area to sell drugs among friends at school and outside school. He was offered a job as a smalltime trafficker to customers in his school and that he did not have to have the capital to become one; instead he just had to credit the drugs he took and then after getting customers' payment, only then the price of drugs is paid to the syndicate through a bank account. Normally, subject was provided with the syndicate with 5 gram syabu costing RM 1000 to be sold or distributed at any given time. He would obtain a net profit of around RM 1500. The income was used for his daily expense, buying more drugs for himself to 'overcome' his addiction. Subject's parents did not know at all about his activities as he was seen going to school without fail, every day. He mentioned further:

“.. my father and mother do not know that I am selling this 'thing' because I go to school just like others. At school, I will also take drugs at the back of the school. After school I will go and sell it in town and motorcycle workshop and many other places. We sell to people whom we are familiar with. I will usually take the stock in the afternoon and in 3 or 4 hours, they will sell like hot cakes. It is a very lucrative business.."

After almost 5 months being involved in illicit drug trafficking (syabu), the subject was confident that he would not be caught red-handed by the authority. One day, as the subject was engrossed in his activities 
selling drugs, he was suddenly ambushed by the police in a public area in the Semenyih town. He was not able to escape from the police as he was occupied counting the money he received out of his 'business' and he was concerned that the money would slip as he was trying to run away. At the time, he was trafficking drugs and was still in his uniform. Upon investigation, they found only a packet of syabu drug left unsold. Following the arrest, after the investigation was complete, the subject was finally charged at the magistrate court, Kajang. He was finally held for trial in a Malaysian prison under juvenile delinquency, where up until now it has been a year that he has been undergoing the punishment over his involvement with drugs. During the interview, he was clearly showing regret over his actions and hoped that the criminals or the illicit drug syndicate who manipulated the juveniles in their ill-activities could be brought down by the authority. Finally, the subject promised to get back on the right track upon his release from prison and would try to find a job if opportunity knocks. However, the subject maintained that it was hard for him to escape and normally the syndicate would hunt ex-drug prisoners who have been released, to work with them again as traffickers. He went on to state:

“...I hope the boss (main traffickers) should be eliminated because they involve us in their own dirty deeds. I am not sure, I don't know what will happen when I am freed, my father must be mad at me and even now, he has never come to visit. Never mind..I will try to find a job, if there is any...but it's hard to run away from them because the syndicate knows me and they have helped me a lot too...I don't know how my fate will be when I am released, sir.."

\section{Suggestion and Conclusion}

As a conclusion to the issue of the threat posed by the syndicate towards the juveniles, undoubtedly the abuse, addiction and trafficking of drugs among the juveniles are a serious problem and needs to be handled at an early age. This study is anticipated to raise an awareness to all authoritative parties about the problems faced, other than serving as guidance in helping to prepare and execute the authority as to handle the juveniles. This group needs to be saved earlier on so that their future sustainability can be ensured, especially in the field of education. They must also be instilled with a sense of pride and ethnic identity so that they will stay close to their positive elements of their respective cultures. The school also needs to build a happy and safe school environment so that the element of absorption of the non-state actor into the lives of these people can well be prevented. Other than that, the concept of human security for the sake of social security, and the cooperation between authoritative departments in the country are crucial to be executed holistically. This is because the non-state actor is a threat to the juveniles, where they serve as an organisation who recruits the juveniles as addicts and subsequently, as drug pushers. A strong implementation of the strategy will be able to balance or prevent any ill impacts played by the non-state actors (criminals, terrorists, illicit drug pushers). Apart from that, parents should be given the exposure to parenting styles that can strengthen the bond between parents and children. This will enable them to monitor activities done by the juveniles effectively and compassionately, also prioritise the inculcation of holistic values in students by way of emphasising on teenage students' academic achievements.

\section{References}

Abdullah, H. W. (2012). He is a Deputy Director of the Narcotics Department, Bukit Aman PDRM, interview on 18 October 2012.

Adeeba, K. (1993). Kamus Dewan Edisi Baru. Kuala Lumpur: Dewan Bahasa dan Pustaka.

Adeeba, K. (2013). Professor from the Dean of Medical Faculty in the Universiti Malaya. Interview on 14 February 2013.

Agensi Antidadah Kebangsaan. (2008). Dasar Dadah Negara. Dalam Talian: http://www.adk.gov.my/download/dasardadahnegara.pdf. Date referred: 24 March 2014.

Agensi Antidadah Kebangsaan. (2013). Laporan Dadah Januari - Disember 2013. Dalam Talian: http://www.adk.gov.my/uploads/laporansep.pdf. Date referred: 24 April 2014.

Agensi Antidadah Kebangsaan. (2009). Garis Panduan Program Intervensi Pelajar (PIP): Institut Pendidikan Bebas Dadah Agensi Antidadah Kebangsaan., Ministry of Domestic Affairs, Kuala Lumpur.

Azlan, I. B. K. (2013). Juvana Offender of Illicit Drug Trafficking. Interview on 10 June 2013.

Berita Harian, 26 June 2013

Daniel, M. (2013). Offender of Illicit Drug Trafficking. Interview on 29 January 2013. 
Harian Metro, 18 Nov 2011.

Harian Metro, 14 June 2012.

Hasnah, G. (1995). Jenayah Remaja Permasalahan dan penyelesaian. Shah Alam: HIZBI.

http://www.drugabuse.gov/about-nida/other-resources Date referred: 24 March 2014.

Hussian, A. H. (2013). Lecturer and Expert Drug Addiction Counselling Psychology Universiti Sains Islam Malaysia. Interview on 7 January 2013.

Ibrahim, M. F. B. H. (2012). He is a lecturer in Universiti Putera Malaysia, a Medical Expert for General Health and Drug Addiction. Interview on 16 April 2012.

Keith, R. \& Wagenen, V. (1991). Writing a Theses Substance and Style Englewood Cliffs, New Jersey Prentice-Hall.

Khulen, R. G. (1982). The Psychology of a Adolescent Development. New York: Harper and Row Publisher.

Karl, C. G. (1975). Psychology of a Adolescent, Edisi 7. New Jersey: Prentice Hall Inc.

Mohamed, M. N. (2008). Memastikan Remaja Bebas Daripada Dadah. Ikon Interactive Sdn. Bhd.

Mohd Nazrul Zulmie (Not real name). (2013). Juvana Offender of Illicit Drug Trafficking. Interview on 10 June 2013.

Nick, C. (2013). Lecturer and Expert in the Field of Drug Addiction from the University of Melbourne, Australia. Interview through the E-mail on 6 May 2013.

Noraini, A. (2000). Kaunseling Remaja. Kuala Lumpur: Utusan Publications \& Distributor Sdn. Bhd.

Nalin, K. M. (2007). Political and Security Challenges in Central Asia; The Drug Trafficking Dimension. Journal of International Studies, 44(2), 158-174.

New Straits Times. 8 September 2009.

Nichol, J. (2011). Central Asia's Security: Issues and Implications for U.S. Interests. Moscow: Congressional Research Service.

Razali, R. (Not real name). (2013). She is a waitress and was a former drug addict. Interview on 2 February 2013.

Rapley, J. (2004). Globalization and Inequality: Neoliberalism's Downward Spiral. Boulder, Colorado: Lynne Rienner.

Ramly, R. B. (2012). He is a General Health Specialist and Deputy Director of the National Anti-Drug Agency, Interview on 21 December 2012.

Sujak, Z. A. (2013). Chairman of INABAH, Private Rehabilitation Center of Drug Issues in Kedah, Malaysia. Interview on 2 February 2013.

Taylor, O. (2008). The Uncertain Future of Human Security in The UN, UNESCO, Blackwell Publishing.

Undang-undang Malaysia. (2006). Akta Kanak-kanak 2001, Akta 611. Malaysian National Printing, Kuala Lumpur.

Utusan Malaysia, 5 May 2011.

Utusan Malaysia, 9 May 2009.

Utusan Malaysia, 13 March 2010.

Utusan Malaysia, 13 February 2013.

Utusan Malaysia, 16 June 2013.

Utusan Malaysia, 26 March 2014.

United Nations Office on Drug and Crime. (2011). World Drug Repot 2011. New York: United Nations Publications.

United Nations Office on Drug and Crime. (2011). World Drug Repot 2011 . New York: United Nations Publications.

William, M. C. \& David, G. W. (2000). Asian Security Handbook. M.E. Sharpe.

Zakiah, D. (1975). Pembinaan Remaja. Jakarta: Bulan Bintang. 